It is obvious, therefore, that practices must, and have, become more valuable, and that in the future they will only be obtainable by purchase. And it is a logical conclusion that the newly qualified man in search of a practice will purchase an already established connexion rather than risk failure and loss of his capital. The "squatter" without introductions, however good a chance he may have had during the early months of the Act coming into force, will have a very poor chance of success, as the industrial classes upon whom he formerly relied will have already become " attached," and the higher classes are proverbially slow to change.-I am, Sir, yours faithfully,

W. W. HaRDWICKE, M.D. St. And.

Carlyle-square, S.W., August 2nd, 1913.

\section{THE PHYLACOGEN TREATMENT OF CHRONIC GONORRHEAL AND RHEUMATIC CONDITIONS.}

\section{To the Editor of THE LANCET.}

Srr,-I see that you have recently published some experiences of medical men in the use of phylacogen. For the last nine months I have been regularly employing phylacogen, and during that time have treated upwards of 30 cases-chronic rheumatism and rheumatoid arthritis with rheumatism phylacogen and chronic gonorrhcal infection with gonorrhoea phylacogen. I submit brief notes of the following two cases, not because they present any exceptional features, but simply as types of the whole series. I may say that with the exception of two cases the results were highly satisfactory.

1. Female, aged 52. This patient had a history of some years' invalidity, and she spent most of her time in bed, only being able to he was up with the assistance of two sticks. The joints of her hands were swollen and the fingers distorted, and she complained of severe pain in the joints and pain extending from the hips to the toes. Oct. 22nd, 1912, 3 c.c. of rheumatism phylacogen were injected subcutaneously; this was followed by slight local and general reaction. Oct. 30 th, 5 c.c. ; patient feeling better, but still could not move and had bad nights. Nov. 1st, 5 c.c.; condition slightly improved. Nov. 5th, 7 e.c.; improvement in joint pains and pain along sciatic nerve. Nov. 7 th, 7 c.c. ; patient obviously better, conld move with more freedom, but still unable to get ont of bed. Nov, 9 th, 10 c.c.; patient much improved. Nov. 10th, pain almost gone. Nov. 12th, 10 c.c.; patient practically free from pain but complained of stiffness. Nov. 13th, patient able to get out of bed and adrised to move affected limbs. Nov. 14th, 10 c.c. : improvement very marked, patient able to walk without assistance of sticks. Nov, 15th, pationt much better and apparently well except for stiffness of the pationt much better and apparently well except for stifness of the joints. All joints could now be mover without pain. The patient steadily improved and was able to perform her household duties till Jan. 4th, when she had a slight relapse, but not of sufficient severity to compel her to use her sticks. Jan. 5th, 7 c.c. were given with good well, has been able to walk unaided, and to perform her household well, bas

2. Male, aged 21. This patient consulted me on Dec. 13th, 1912, and complained of lassitude, want of energy, and feeling run down. He had not felt in really good health since an attack of gonorrhcea some 18 months previously. The discharge "came and went," but he had never entirely got rid of it. Examination per rectum showed the prostate gland was indurated. Gonorrhcea phylacogen was administered, 5 c.c. being injected subcutaneously into the arm at 7.30 P.M. on Dec. 13th. At 10 P.M. the arm har become intensely red and painful, accompanied by numbness and limitation of movement; headache, but no other general reaction and no focal reaction in the urethra. Dec. 15th, 7 c.c. ; local reaction as before in about six hours, together with severe headache and feeling of nausea but patient was able to perform his duties next day. A greenish-yellow discharge appeared ; urination painful and frequent, “just like the acute attack." Dec. 17th, 7 c.c. ; local and general reaction less severe discharge less purulent and less abundant; felt better in genera health. Dec. 19th, discharge had almost stopped. Dec. 21st, 7 c.c. little reaction. Dec. 22nd, discharged entirely ceased and patient apparently well. Since that time the patient has been frequently seen there has been no recurrence of the trouble, and he feels better than he has done in the past 18 months.

I have also treated septic infections with mixed infection phylacogen with satisfactory results.

I am, Sir, yours faithfully, Alex. McCalL, M.D. Glasg

Uxbridge-road, W., July 25th, 1913.

The Director-General of Public Health reports by telegram that the small-pox epidemic now existing in Sydney is of very mild type, similar to that in Canada. There have been 400 cases, no deaths, and no patient has been dangerously ill.

\section{SEVENTEENTH INTERNATIONAL CONGRESS OF MEDICINE.}

THE International Medical Congress was formally opened on Wednesday, August 6th, by His Royal Highness Prince Arthur of Connaught, acting on behalf of His Majesty the King.

In order that visitors attending the Congress may have opportunities of seeing the work of the London hospitals, arrangements have been made for this purpose by the authorities of the principal general hospitals, and these are announced in the official daily journal which is issued to members at the Albert Hall. The special hospitals can be visited by arrangement with the secretaries of the individual scientific sections.

The Museum of the Royal College of Surgeons of England, Lincoln's Inn Fields, W.C., has been open to members of the Congress, and will be open from 10 A.M. to 5 P.M. on August 8th, and from 10 A.M. to 1 P.M. on August 9th. The library of the College will be open to members of Congress from 10 A.M. to 1 P.M. on August 9th. The Royal Society of Medicine, 1, Wimpole-street, admits members of Congress to its library. The Council of the Royal Sanitary Institute, 90, Buckingham Palace-road, S.W., invites members of Congress to visit the Parkes Museum of Hygiene and their buildings, and offers them the use of the library and reading-room and the members' common room.

On the occasion of the International Congress of Medicine the Royal College of Surgeons of England conferred the honorary Fellowship of the College upon the following foreign and colonial surgeons: Professor R. Bastianelli, Rome; Professor A. Bier, Berlin; Mr. F. D. Bird, Melbourne; Dr. G. W. Crile, Cleveland, U.S.A.; Dr. H. Cushing, Harvard; Dr. A. F. von Eiselsberg, Vienna; Dr. E. Fuchs, Vienna; Dr. H. Hartmann, Paris ; Professor W. Korte, Berlin; Dr. W. J. Mayo, Rochester, U.S.A. ; Dr. A. Monprofit, Paris; Dr. J. B. Murphy, Chicago ; Dr. J. Nicolaysen, Christiania; Dr. F. J. Shepherd, Montreal ; and Professor T. Tuffier, Paris.

Special arrangements have been made for divine services on Sunday, August 10th. In St. Paul's Cathedral a special sermon will be preached in connexion with the Congress at the 10.30 A.M. service by the Very Rev. the Dean of St. Paul's. In Westminster Abbey at the 10 A.M. service a special sermon will be preached by the Right Rev. Bishop Ryle, Dean of Westminster. In Westminster Cathedral the service in connexion with the Congress will be a solemn High Mass beginning at $10.30 \mathrm{~A} . \mathrm{x}$., during which a special sermon will be preached by His Eminence Cardinal Bourne, Archbishop of Westminster. Seats will be reserved for members of the Congress, and members are requested to put down their names at the Albert Hall for these services not later than to-day (Friday, August 8th), in order that sufficient seats may be reserved. The offices of the Congress will be closed on Sunday.

Sir Thomas Barlow, in his Presidential Address before the opening session of the Congress, which we print in full elsewhere, made happy references to the pioneers of medicine who gathered round his predecessor, Sir James Paget, 32 years ago, when the International Medical Congress last met in London. Sir Thomas Barlow justly pointed out that the Congress of 1881 was remarkable not only for the number of great men who attended it, but also for the fact that it 